\title{
Exiguobacterium oxidotolerans sp. nov., a novel alkaliphile exhibiting high catalase activity
}

\author{
Correspondence \\ Isao Yumoto \\ i.yumoto@aist.go.jp
}

\author{
Isao Yumoto, ${ }^{1,2}$ Megumi Hishinuma-Narisawa, ${ }^{1}$ Kikue Hirota, ${ }^{1}$ \\ Tomohiro Shingyo, ${ }^{1,3}$ Fumihiko Takebe, ${ }^{1,3}$ Yoshinobu Nodasaka, ${ }^{4}$ \\ Hidetoshi Matsuyama ${ }^{3}$ and Isao Hara ${ }^{1}$ \\ ${ }^{1}$ National Institute of Advanced Industrial Science and Technology, Tsukisamu-Higashi, \\ Toyohira-ku, Sapporo 062-8517, Japan \\ ${ }^{2}$ Graduate School of Agriculture, Hokkaido University, Kita-ku, Sapporo 060-8589, Japan \\ ${ }^{3}$ Hokkaido Tokai University, Minaminosawa, Minami-ku, Sapporo 005-8601, Japan \\ ${ }^{4}$ School of Dentistry, Hokkaido University, Kita-ku, Sapporo 060-8586, Japan
}

There are micro-organisms living in environments of extreme temperature, $\mathrm{pH}$, salinity and hydropressure (Horikoshi \& Grant, 1991). These micro-organisms have apparently acquired the ability to survive under such environmental conditions through long-term evolutionary processes, and they possess specific mechanisms for survival in such extreme environments. Among such adaptational processes, not only the micro-organisms themselves might be affected by environmental conditions and induced to acquire adaptation-suitable features, but so too might production of organic molecules within the micro-organisms, such as enzymes and proteins that sustain their metabolism. Although $\mathrm{H}_{2} \mathrm{O}_{2}$ production and interaction with micro-organisms often occur in nature (Haas \& Goebel, 1992), there have been only a few reports of specific micro-organisms that inhabit environments

Published online ahead of print on 23 April 2004 as DOI 10.1099/ ijs.0.63129-0.

The GenBank/EMBL/DDBJ accession number for the 16S rRNA gene sequence of strain $\mathrm{T}-2-2^{\top}$ is $\mathrm{AB} 105164$.

Details of the catalase activity of strain $\mathrm{T}-2-2^{\top}$ and reference strains are available as supplementary material in IJSEM Online. with hyperoxidative stress caused by factors such as high $\mathrm{H}_{2} \mathrm{O}_{2}$ concentrations (Yumoto et al., 1999).

Aerobic organisms normally possess specific enzymes to eliminate $\mathrm{H}_{2} \mathrm{O}_{2}$, which are produced extracellularly as well as intracellularly. Catalase is one such well-known enzyme. It has been reported that catalase plays an important role in certain micro-organisms in obtaining niches in host cells. For example, in Vibrio fischeri, catalase KatA is required for its colonization of the light organ of squid (Visick \& Ruby, 1998). The production of catalase and $\mathrm{H}_{2} \mathrm{O}_{2}$ has been reported in several other cases of either parasitic or symbiotic relationships between microorganisms and their host (Katsuwon \& Anderson, 1992; Rocha et al., 1996). If there is a micro-organism that is able to survive in an environment with high $\mathrm{H}_{2} \mathrm{O}_{2}$ concentrations, it can be expected that this micro-organism will possess an enzyme (e.g. catalase) exhibiting a high $\mathrm{H}_{2} \mathrm{O}_{2}$-degrading ability. In the present study, we isolated a micro-organism exhibiting a high tolerance to $\mathrm{H}_{2} \mathrm{O}_{2}$ and an extraordinarily high catalase activity. It was of considerable interest to identify the taxonomic position of such a new type of extremophile. Phenotypic and chemotaxonomic characteristics were examined, as well as the 
phylogenetic position of the isolate, and it was found that the strain should be classified as representing a novel species belonging to the genus Exiguobacterium.

A water sample was obtained from a drain pool of a fish processing plant in Hokkaido in which $\mathrm{H}_{2} \mathrm{O}_{2}$ is used as a bleaching agent. It was plated onto a $10 \mathrm{mM} \mathrm{H}_{2} \mathrm{O}_{2}$ (Wako Pure Chemical)-containing PYS-2 agar plate ( $\mathrm{pH} 7 \cdot 5)$ containing 8 g polypeptone (Nihon Pharmaceuticals), 3 g yeast extract (Kyokuto) and $5 \mathrm{~g} \mathrm{NaCl}$, and incubated at $27^{\circ} \mathrm{C}$ for 1 week. From the incubated plate, eight colonies were obtained, six white-coloured colonies and two orangecoloured colonies. $\mathrm{H}_{2} \mathrm{O}_{2}$ decomposition activity of the eight colonies was measured. Among them, bacterial strain T-2-2 ${ }^{\mathrm{T}}$ exhibiting unusual $\mathrm{H}_{2} \mathrm{O}_{2}$ decomposition activity was isolated. For DNA-DNA hybridization, Exiguobacterium antarcticum DSM $14480^{\mathrm{T}}$, Exiguobacterium undae DSM $14481^{\mathrm{T}}$, Exiguobacterium acetylicum JCM $1968^{\mathrm{T}}$ and Exiguobacterium aurantiacum NCIMB $11798^{\mathrm{T}}$ were used. These micro-organisms were grown in PYS-2 medium at $27^{\circ} \mathrm{C}$ until the early-stationary phase of growth.

For phenotypic characterization, PYS-2 medium was used as the basal medium. The culture was incubated at $27^{\circ} \mathrm{C}$ for 2 weeks unless otherwise stated, and the experiment repeated three times. Morphological, physiological and biochemical tests were performed as described in Barrow \& Feltham (1993). Carbohydrate metabolism was tested by the method of Hugh \& Leifson (1953), and the result checked daily until 2 weeks after inoculation. Alginase activity was determined after an inoculated agar plate was overlaid with ethanol following cultivation for 10 days. For comparison of strain $\mathrm{T}-2-2^{\mathrm{T}}$ with other Exiguobacterium species in acid production from sugars and enzymic activities, API $50 \mathrm{CH}$ (bioMérieux) and API ZYM (bioMérieux) were used, respectively.

For the comparative study of catalase activity, Micrococcus luteus JCM $1464^{\mathrm{T}}$, Exiguobacterium aurantiacum NCIMB $11798^{\mathrm{T}}$, Exiguobacterium acetylicum JCM $1968^{\mathrm{T}}$, Aeromonas hydrophila JCM $1027^{\mathrm{T}}$, Alcaligenes faecalis (laboratory strain), Pseudomonas fluorescens JCM 5963 ${ }^{\mathrm{T}}$, Staphylococcus aureus IAM $12544^{\mathrm{T}}$, Escherichia coli IAM 1264 and Vibrio parahaemolyticus JCM 2147 were used. Cells for catalase activity determination were incubated in a $500 \mathrm{ml}$ flask containing $100 \mathrm{ml}$ PYSG medium ( $\mathrm{pH} 7 \cdot 5)$ containing PYS-2 plus $0.5 \%$ sodium glutamate, which was set on a rotary shaker (140 r.p.m.) and maintained at $27^{\circ} \mathrm{C}$ until growth reached the late-exponential to early-stationary phase. A cell extract was obtained as follows. Cells were harvested by centrifugation and disrupted with a French pressure cell (SLM-AMINCO) at 20000 p.s.i. (138 MPa). After removing unbroken cells by centrifugation $(10000 \mathrm{~g}$ for $15 \mathrm{~min}$ ), the resulting fluid was used as the cell extract. Catalase activity was assayed at $\mathrm{pH} 7$ using $30 \mathrm{mM} \mathrm{H}_{2} \mathrm{O}_{2}$ measured spectrophotometrically as described previously (Yumoto et al., 1999). The amount of enzyme activity that decomposed $1 \mu \mathrm{mol} \mathrm{H}_{2} \mathrm{O}_{2} \min ^{-1}$ was defined as $1 \mathrm{U}$ of activity. Enzyme activity was estimated five times for each sample, using at least three independent samples.

For electron microscopic observation, cells were cultivated on PYS-2 agar at $27^{\circ} \mathrm{C}$ for 1 day. A small drop of the suspension was placed on a carbon-coated copper grid, negatively stained with $1 \%$ phosphotungstic acid and observed using transmission electron microscopy (H-800, Hitachi) (Yumoto et al., 2002).

Analyses of whole-cell fatty acids and isoprenoid quinones were performed as described previously (Yumoto et al., 2001, 2002). Analysis of cell wall amino acids was performed using the methods of Schleifer \& Kandler (1972). Polar lipids were analysed by the methods of Minnikin et al. (1979) and Collins \& Jones (1980).

Bacterial DNA was prepared according to the method of Marmur (1961). DNA base composition was determined by the method of Tamaoka \& Komagata (1984). DNADNA relatedness was determined fluorometrically by the method of Ezaki et al. (1989) using photobiotin-labelled DNA probes and black microplates.

The 16S rRNA gene sequence corresponding to positions 27-1519 in the 16S rRNA gene sequence of Escherichia coli (Brosius et al., 1978) was amplified by PCR. The PCR product (about $1.5 \mathrm{~kb}$ ) was sequenced directly by the dideoxynucleotide chain-termination method using a DNA sequencer (PRISM 377; Applied Biosystems). Closest relatives to the sequence were retrieved from GenBank. Multiple alignments of the sequences were performed and the nucleotide substitution rate ( $K_{\text {nuc }}$ value) was calculated. A phylogenetic tree was constructed by the neighbourjoining method (Kimura, 1980; Saitou \& Nei, 1987) using the CLUSTAL W program (Thompson et al., 1994). Similarity values for sequences were calculated using the GENETYX computer program (Software Development).

Morphological, physiological and biochemical characteristics of the isolate are given in the species description. Phenotypic characterization of the isolate showed that it formed an orange or yellow colony, with Gram-positive, non-sporeforming rods $(0.6-0.7 \times 0.6-1.8 \mu \mathrm{m})$ with peritrichous flagella (Fig. 1). It exhibited positive catalase and oxidase reactions and produced acid from several carbohydrates under aerobic conditions. It grew at $4-40{ }^{\circ} \mathrm{C}$ (optimum growth temperature was $34^{\circ} \mathrm{C}$ ), $\mathrm{pH} 7-10$ and $0-12 \% \mathrm{NaCl}$.

GLC analysis of strain $\mathrm{T}-2-2^{\mathrm{T}}$ revealed that the fatty acids comprised iso- $\mathrm{C}_{12: 0}(1 \cdot 4 \%)$, iso- $\mathrm{C}_{13: 0}(8 \cdot 5 \%)$, anteiso$\mathrm{C}_{13: 0}(9 \cdot 0 \%)$, iso- $\mathrm{C}_{14: 0}(2 \cdot 7 \%)$, iso- $\mathrm{C}_{15: 0}(20 \cdot 7 \%)$, anteiso- $\mathrm{C}_{15: 0}(4 \cdot 2 \%)$, iso- $\mathrm{C}_{16: 0}(7 \cdot 1 \%)$, iso- $\mathrm{C}_{16: 1}(2 \cdot 4 \%)$, $\mathrm{C}_{16: 0}(2 \cdot 9 \%), \mathrm{C}_{16: 1}(3 \cdot 0 \%)$, iso- $\mathrm{C}_{17: 0}(23 \cdot 3 \%)$, anteiso$\mathrm{C}_{17: 0}(6 \cdot 1 \%)$, iso- $\mathrm{C}_{17: 1}(6 \cdot 2 \%), \mathrm{C}_{17: 1}(1 \cdot 2 \%)$ and $\mathrm{C}_{18: 1}$ $(1.6 \%)$; the major isoprenoid quinone was menaquinone7. DNA G+C content was $46 \cdot 7 \mathrm{~mol} \%$. Cell wall amino acid was lysine as the diagnostic amino acid (Lys-Gly type). Polar lipids consisted of phosphatidylglycerol, 


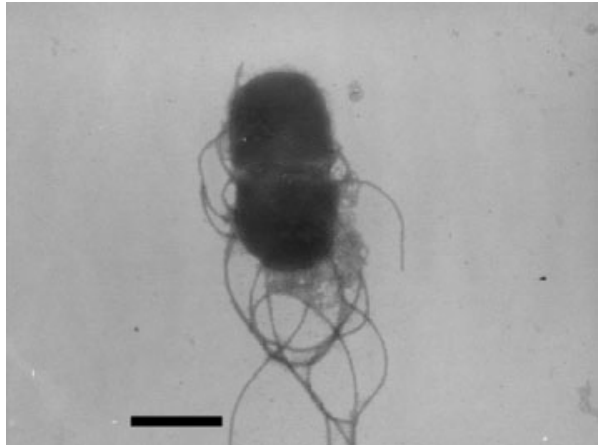

Fig. 1. Transmission electron micrograph of Exiguobacterium oxidotolerans T-2-2 ${ }^{\top}$ incubated on PYS-2 agar for $24 \mathrm{~h}$ at $27^{\circ} \mathrm{C}$. Negatively stained cells of $\mathrm{T}-2-2^{\mathrm{T}}$ showing peritrichous flagellation. Bar, $1 \mu \mathrm{m}$.

diphosphatidylglycerol, phosphatidylethanolamine, phosphatidylserine and phosphatidylinositol. These chemotaxonomic characteristics indicated that the isolate belonged to the genus Exiguobacterium.
Details of the catalase activity of strain $\mathrm{T}-2-2^{\mathrm{T}}$ and reference strains are available as supplementary material in IJSEM Online. The catalase activity of $\mathrm{T}-2-2^{\mathrm{T}}$ exhibited approximately $25000 \mathrm{U}$ (mg protein) ${ }^{-1}$, two to three orders of magnitude higher than those of the other reference strains. Catalase activity of $\mathrm{T}-2-2^{\mathrm{T}}$ is 567 -fold higher than that of Escherichia coli [44.1 $\mathrm{U}$ (mg protein $)^{-1}$.

The almost-complete 16S rRNA gene sequence of T-2-2 ${ }^{\mathrm{T}}$, comprising $1515 \mathrm{nt}$, was compared with all other known 16S rRNA gene sequences, and a phylogenetic tree was constructed using related taxa. The phylogenetic tree indicated that $\mathrm{T}-2-2^{\mathrm{T}}$ falls within the genus Exiguobacterium (Fig. 2). $16 \mathrm{~S}$ rRNA gene sequence similarities of T-2-2 to Exiguobacterium antarcticum, Exiguobacterium undae, Exiguobacterium acetylicum and Exiguobacterium aurantiacum were $98 \cdot 6,98 \cdot 4,98 \cdot 1$ and $93 \cdot 6 \%$, respectively. On the basis of $16 \mathrm{~S}$ rRNA gene sequence analysis, $\mathrm{T}-2-2^{\mathrm{T}}$ is a member of the genus Exiguobacterium.

Levels of DNA-DNA relatedness were estimated by using all four recognized species of Exiguobacterium. Exiguobacterium antarcticum DSM $14480^{\mathrm{T}}$, Exiguobacterium undae

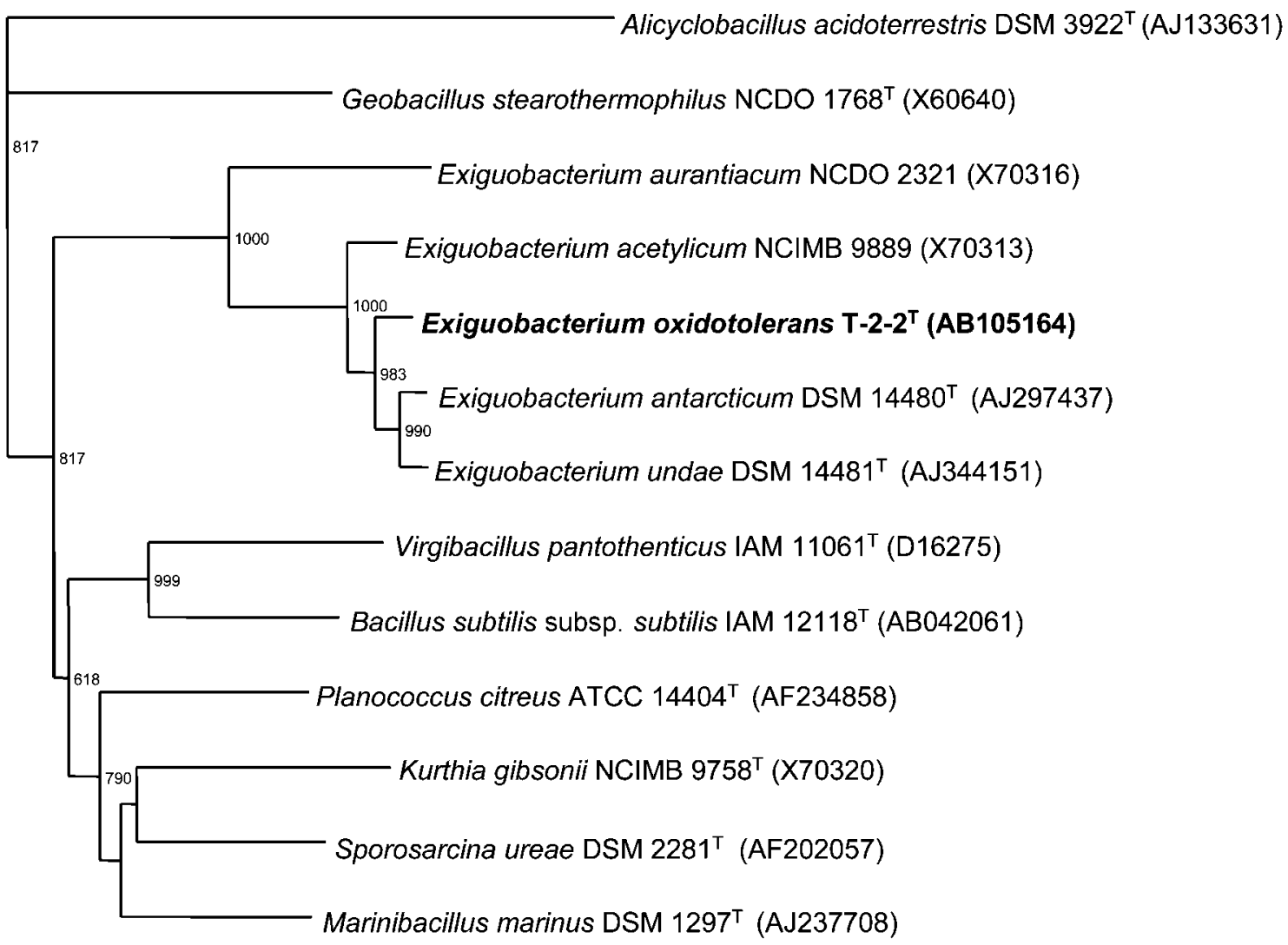

0.01

Fig. 2. Phylogenetic tree derived from $16 \mathrm{~S}$ rRNA gene sequence data of Exiguobacterium oxidotolerans $\mathrm{T}-2-2^{\top}$, other Exiguobacterium species and some other related organisms using the neighbour-joining method. Numbers indicate bootstrap values greater than 500 . Bar, $0.01 K_{\text {nuc }}$ units. 
DSM $14481^{\mathrm{T}}$, Exiguobacterium acetylicum JCM $1968^{\mathrm{T}}$ and Exiguobacterium aurantiacum NCIMB $11798^{\mathrm{T}}$ revealed a DNA-DNA relatedness range of $20-44 \%$. On the basis of these results, $\mathrm{T}-2-2^{\mathrm{T}}$ was considered to represent a novel species.

Strain $\mathrm{T}-2-2^{\mathrm{T}}$ also differed from the other relatively closely related Exiguobacterium species in terms of the following physiological and biochemical characteristics: growth temperature range, acid production from several substrates and enzymic activities (Table 1).

On the basis of the above results, the isolate is considered to represent a novel species, for which the name Exiguobacterium oxidotolerans sp. nov. is proposed.

\section{Description of Exiguobacterium oxidotolerans sp. nov.}

Exiguobacterium oxidotolerans (ox.id.o.tol.e'rans. N.L. v. oxido to oxidize; L. part. adj. tolerans tolerating; N.L. part. adj. oxidotolerans oxidation-tolerant).

Cells are rod-shaped $(0.6-0.7 \times 0.6-1.8 \mu \mathrm{m})$, Grampositive and with peritrichous flagella. Colonies are circular (1-5 $\mathrm{mm}$ in diameter), with entire margins and are orange- or yellow-coloured. Catalase and oxidase reactions are positive. Growth occurs at pH 7-10. Grows at $12 \%$ $\mathrm{NaCl}$ but not at $15 \% \mathrm{NaCl}$. Grows at $4-40{ }^{\circ} \mathrm{C}$ (optimum $34^{\circ} \mathrm{C}$ ). The organism is positive for methyl red, ONPG test, $\beta$-galactosidase and acid phosphatase activities, but negative for Voges-Proskauer test, reduction of $\mathrm{NO}_{3}^{-}$to

Table 1. Characteristics of Exiguobacterium oxidotolerans sp. nov. and related species

1, E. oxidotolerans T-2-2 $2^{\mathrm{T}}$ 2, E. acetylicum JCM $1968^{\mathrm{T}} ; 3$, E. aurantiacum DSM $6208^{\mathrm{T}}$; 4, E. undae DSM $14481^{\mathrm{T}}$; 5, E. antarcticum DSM $14480^{\mathrm{T}}$. +, Positive; -, negative; v, variable; ND, no data.

\begin{tabular}{|lccccc|}
\hline Characteristic & $\mathbf{1}$ & $\mathbf{2}$ & $\mathbf{3}$ & $\mathbf{4}$ & $\mathbf{5}$ \\
\hline $\begin{array}{l}\text { Growth temperature } \\
\text { range }\left({ }^{\circ} \mathrm{C}\right)\end{array}$ & $4-36$ & $7-43^{*}$ & $\mathrm{ND}$ & $20-41^{*}$ & $20-41^{*}$ \\
Acid produced from: & & & & & \\
$\quad$ Galactose & - & - & - & + & + \\
D-Mannose & + & + & - & + & + \\
Melibiose & + & - & - & + & - \\
D-Raffinose & - & - & - & $\mathrm{V}$ & - \\
Rhamnose & + & - & - & + & - \\
Methyl $\alpha$-D-glucoside & - & - & + & + & - \\
Amygdalin & + & - & + & + & + \\
Ribose & + & - & + & + & + \\
$\quad$ Mannitol & + & + & + & + & - \\
Enzymic activities & & & & & \\
$\quad \beta$-Galactosidase & + & + & - & + & + \\
Acid phosphatase & + & - & - & + & + \\
\hline
\end{tabular}

${ }^{\star}$ Data from Collins et al. (1983) and Frühling et al. (2002).
$\mathrm{NO}_{2}^{-}$, and indole and $\mathrm{H}_{2} \mathrm{~S}$ production. It hydrolyses casein, gelatin, starch and DNA, but not chitin, alginic acid, and Tweens 20, 40, 60 and 80. It produces acid from D-fructose, D-maltose, D-mannose, melibiose, raffinose, rhamnose, amygdalin, ribose and mannitol (weak), but not from L-arabinose, sucrose, D-xylose, myo-inositol, sorbitol, D-galactose, L-rhamnose or trehalose. The major isoprenoid quinone is menaquinone-7. The peptidoglycan type is Lys-Gly. Polar lipids consist of phosphatidylglycerol, diphosphatidylglycerol, phosphatidylethanolamine, phosphatidylserine and phosphatidylinositol. Major fatty acids are iso- $\mathrm{C}_{13: 0}$, anteiso- $\mathrm{C}_{13: 0}$, iso- $\mathrm{C}_{15: 0}$, iso- $\mathrm{C}_{16: 0}$, iso- $\mathrm{C}_{17: 0}$, anteiso- $\mathrm{C}_{17: 0}$ and iso- $\mathrm{C}_{17: 1}$. The DNA G+C content is $46 \cdot 7 \%$.

The type strain is $\mathrm{T}-2-2^{\mathrm{T}} \quad\left(=\mathrm{JCM} \quad 12280^{\mathrm{T}}=\mathrm{NCIMB}\right.$ $\left.13980^{\mathrm{T}}\right)$.

\section{Acknowledgements}

This study was supported by the Japanese Ministry of the Environment.

\section{References}

Barrow, G. I. \& Feltham, R. K. A. (editors) (1993). Cowan and Steel's Manual for the Identification of Medical Bacteria, 3rd edn. Cambridge: Cambridge University Press.

Brosius, J., Palmer, M. L., Kennedy, P. J. \& Noller, H. F. (1978). Complete nucleotide sequence of a $16 \mathrm{~S}$ ribosomal RNA gene from Escherichia coli. Proc Natl Acad Sci U S A 75, 4801-4805.

Collins, M. D. \& Jones, D. (1980). Lipids in the classification and identification of coryneform bacteria containing peptidoglycans based on 2,4-diaminobutyric acids. J Appl Bacteriol 48, 452-470.

Collins, M. D., Lund, B. M., Farrow, J. A. E. \& Schleifer, K. H. (1983). Chemotaxonomic study of an alkalophilic bacterium, Exiguobacterium aurantiacum gen. nov., sp. nov. J Gen Microbiol 129, 2037-2042.

Ezaki, T., Hashimoto, Y. \& Yabuuchi, E. (1989). Fluorometric deoxyribonucleic acid-deoxyribonucleic acid hybridization in microdilution wells as an alternative to membrane filter hybridization in which radioisotopes are used to determine genetic relatedness among bacterial strains. Int J Syst Bacteriol 39, 224-229.

Frühling, A., Schumann, P., Hippe, H., Sträubler, B. \& Stackbrandt, E. (2002). Exiguobacterium undae sp. nov. and Exiguobacterium antarcticum sp. nov. Int J Syst Evol Microbiol 52, 1171-1176.

Haas, A. \& Goebel, W. (1992). Microbial strategies to prevent oxygen-dependent killing by phagocytes. Free Radic Res Commun 16, 137-157.

Horikoshi, K. \& Grant, W. D. (1991). Superbugs; Microorganisms in Extreme Environments. Tokyo: Japan Scientific Society Press.

Hugh, R. \& Leifson, E. (1953). The taxonomic significance of fermentative versus oxidative metabolism of carbohydrates by various gram negative bacteria. J Bacteriol 66, 24-26.

Katsuwon, J. \& Anderson, A. J. (1992). Characterization of catalase activities in root colonizing isolates of Pseudomonas putida. Can J Microbiol 38, 1026-1032.

Kimura, M. (1980). A simple method for estimating evolutionary rates of base substitutions through comparative studies of nucleotide sequences. J Mol Evol 16, 111-120. 
Marmur, J. (1961). A procedure for the isolation of deoxyribonucleic acid from microorganisms. J Mol Biol 3, 208-218.

Minnikin, D. E., Collins, M. D. \& Goodfellow, M. (1979). Fatty acid and polar lipid composition in the classification of Cellulomonas, Oerskovia and related taxa. J Appl Bacteriol 47, 87-95.

Rocha, E. R., Selby, T., Coleman, J. P. \& Smith, C. J. (1996). Oxidative stress response in an anaerobe, Bacteroides fragilis: a role for catalase in protection against hydrogen peroxide. J Bacteriol 178, 6895-6903.

Saitou, N. \& Nei, M. (1987). The neighbor-joining method: a new method for reconstructing phylogenetic trees. Mol Biol Evol 4, 406-425.

Schleifer, K. H. \& Kandler, O. (1972). Peptidoglycan types of bacterial cell wall and their taxonomic implications. Bacteriol Rev 36, 407-477.

Tamaoka, J. \& Komagata, K. (1984). Determination of DNA base composition by reversed-phase high-performance liquid chromatography. FEMS Microbiol Lett 25, 125-128.

Thompson, J. D., Higgins, D. G. \& Gibson, T. J. (1994). CLUSTAL W: improving the sensitivity of progressive multiple sequence alignment through sequence weighting, position-specific gap penalties and weight matrix choice. Nucleic Acids Res 22, 4673-4680.

Visick, K. L. \& Ruby, E. G. (1998). The periplasmic, group III catalase of Vibrio fischeri is required from normal symbiotic competence and is induced both by oxidative stress and by approach to stationary phase. J Bacteriol 180, 2087-2092.

Yumoto, I., Iwata, H., Sawabe, T., Ueno, K., Ichise, N., Matsuyama, H., Okuyama, H. \& Kawasaki, K. (1999). Characterization of a facultatively psychrophilic bacterium, Vibrio rumoiensis sp. nov., that exhibits high catalase activity. Appl Environ Microbiol 65, 67-72.

Yumoto, I., Yamazaki, K., Hishinuma, M., Nodasaka, Y., Suemori, A., Nakajima, K., Inoue, N. \& Kawasaki, K. (2001). Pseudomonas alcaliphila sp. nov., a novel facultatively psychrophilic alkaliphile isolated from seawater. Int J Syst Evol Microbiol 51, 349-355.

Yumoto, I., Nakamura, A., Iwata, H., Kojima, K., Kusumoto, K., Nodasaka, Y. \& Matsuyama, H. (2002). Dietzia psychralcaliphila sp. nov., a novel, facultatively psychrophilic alkaliphile that grows on hydrocarbons. Int J Syst Evol Microbiol 52, 85-90. 